\title{
Does the region still have relevance? (re)considering "regional" political ecology
}

\author{
Innisfree McKinnon ${ }^{1}$ \\ Colleen C. Hiner \\ University of Wisconsin-Stout, USA \\ Texas State University, USA
}

\begin{abstract}
Although the field of political ecology began as fundamentally regional, a clear, coherent regional political ecology approach has failed to emerge. This introductory essay frames a collection of articles compiled to take up the idea of pursuing a specifically regional political ecology, discussing both the problematic and the beneficial aspects of regions and regional approaches. In this introduction, we discuss the strengths and the weaknesses of using the region as a heuristic within the field. Our focus, and that of the articles introduced, is to consider what analytical work this concept can do, addressing the question: how and why how are regions useful within political ecology? Our intention is not to provide a guide to using the concept in political ecology but rather to highlight how regions are currently being used, and to reopen discussions of the utility of the concept for scholars explicitly working towards justice and sustainability in a variety of contexts. After describing the value of a using regional political ecology approach, we emphasize the work still yet to be done, prompting other scholars to consider regional political ecology approaches as they do the work that they do.
\end{abstract}

Keywords: regional political ecology; region; political ecology; geography

\section{Résumé}

Bien que, dès ses débuts, l'écologie politique ait été fondamentalement régionale, aucune approche régionale claire et cohérente en écologie politique n'a réussi à voir le jour. Cet article introductif présente une collection d'articles compilés dans le but de promouvoir l'idée d'une écologie politique spécifiquement régionale, traitant aussi bien les aspects problématiques que les côtés bénéfiques du concept de région et des approches régionales. Dans cette introduction, nous exposons à la fois les forces et les faiblesses de l'utilisation de la région en tant qu'heuristique dans le domaine de l'écologie politique. Notre objectif, et celui des articles présentés, est d'explorer le type de travail d'analyse offert par ce concept et ce, en répondant à la question: comment et pourquoi les régions sont-elles utiles dans le cadre de l'écologie politique? Notre intention n'est pas de fournir un guide d'usage du concept en écologie politique mais plutôt de mettre en lumière la manière dont la région est actuellement utilisée et de reouvrir la discussion sur l'utilité du concept pour les chercheurs travaillant explicitement à plus de justice et de durabilité dans divers contextes. Après avoir présenté l'importance de l'utilisation d'une approche régionale de l'écologie politique, nous mettons l'accent sur le travail restant à faire, incitant les chercheurs à envisager l'utilisation des approches régionales en écologie politique dans le cadre de leurs travaux.

Mots clés: écologie politique régionale; région; écologie politique; géographie

\footnotetext{
${ }^{1}$ Dr. Innisfree McKinnon, Assistant Professor, Social Sciences Department, University of Wisconsin-Stout, Menomonie, WI, USA. Email: mckinnoni "at" uwstout.edu. Dr. Colleen Hiner, Assistant Professor, Department of Geography, Texas State University, San Marcos, TX, USA. Email: cchiner "at" txstate.edu. Our appreciation goes out to all those who participated in the 2014 paper and panel sessions on this topic at the Association of American Geographers meeting in Tampa, FL, including Ryan E. Galt, Jeffrey Jenkins, Soren C. Larsen, Jonathan London, Rod Neumann, Paul Robbins, Dianne E. Rocheleau, Laura Taylor, and Peter Walker, some of whom contributed to this collection. Our thanks also to those who attended the session and ultimately became contributors to this special issue, Valentine Cadieux and Gregory Simon. In addition, we would also like to thank: two anonymous reviewers for commenting on the articles included herein; Maël Le Noc for graciously providing the French abstract translations; and the editorial leadership at the Journal of Political Ecology (namely Casey Walsh and Simon Batterbury) who shepherded this collection through review and publication.This is the introductory paper in Innisfree McKinnon and Colleen Hiner (eds.) 2015. "(Re)considering regional political ecology?", Special Section of the Journal of Political Ecology 23: 115-203.
} 


\section{Resumen}

Aunque el campo de ecología política comenzó siendo fundamentalmente regional, una clara, coherente ecología política regional no ha logrado surgir. Este ensayo introductorio enmarca una colección de textos compilados para adoptar la idea de perseguir una ecología política específicamente regional, discutiendo tanto la problemática como los aspectos benéficos de regiones y enfoques regionales. En esta introducción discutimos tanto las fortalezas como las debilidades de usar a la región heurísticamente dentro de ecología política. Nuestro enfoque, y el de los textos que introducimos, es el de considerar el trabajo analítico que este concepto puede lograr, atendiendo a la pregunta: ¿Cómo y porqué son las regiones útiles dentro de la ecología política? Nuestra intención no es proveer una guía de cómo usar el concepto en ecología política sino recalcar cómo la idea se emplea actualmente y replantear la discusión al respecto de la utilidad del concepto para académicos que trabajan explícitamente hacia la justicia y sustentabilidad en una variedad de contextos. Tras describir el valor de usar el enfoque de ecología política regional, enfatizamos el trabajo que aún falta por hacer, alentando a otros académicos a considerar el uso de enfoques de ecología política regional en sus propios trabajos.

Palabras clave: ecología política regional; región; ecología política; geografía

\section{Inspiration for the special section}

The field of political ecology began as fundamentally regional, as even Blaikie and Brookfield (1987) framed their approach as regional political ecology. Yet, as the field has developed, the use of "region" as a key framing concept has been inconsistent, seeming at times to drop out analyses altogether as well as being applied by scholars in varying ways. Now, almost thirty years later, political ecology has grown into a sprawling field, one which is sometimes accused of incoherency. Indeed, there is no one political ecology approach, rather political ecologists tend to use what Galt (2016: 127) describes as "an everything-but-thekitchen-sink methodological approach." Accordingly, Walker (2002) proposed that a renewed emphasis on the region within political ecology may simultaneously provide useful analytical purchase and assist in the breakdown of problematic analytical binaries. Yet, more than a decade later, a clear, coherent regional political ecology approach has failed to emerge.

The articles in this Section take up the idea of a specifically regional political ecology, discussing the problematic and the beneficial aspects of regions and regional approaches. In this introduction, we discuss the strengths and the weaknesses of using the region as a heuristic within political ecology (Hiner 2016; Jenkins 2016). Like Simon (2016) our focus is on what analytical work this concept can do, addressing the question: how and why how are regions useful within political ecology? Our intention is not to provide a guide to using the concept in political ecology but rather to highlight how the idea is currently being used, and to reopen discussions of the utility of the region for scholars explicitly working towards justice and sustainability in a variety of contexts.

Our initial interest in an extended discussion of regional political ecology stems from the potential for regional approaches to disrupt ongoing and newly developing spatial and theoretical divides in political ecology. As political ecologists whose work focuses on North America, we found ourselves at conferences primarily presenting to and interacting with scholars whose work also focuses on rural parts of North America, Europe, and Australia. This led us to begin organizing paper sessions at professional meetings that attempted to bridge the rural/urban and developing/developed world binaries. At the American Association of Geographers (AAG) meeting in Los Angeles in 2013 we organized as set of sessions called Political ecology across the rural-urban divide which attracted a wide-ranging set of papers that questioned a simple rural/urban division, and also included studies from a variety of developed world and developing world locations. Thus studies of land use debates in Massachusetts and Pennsylvania were discussed in conjunction with a study of cattle trespassing across the U.S./Mexico border, and the identity of the indigenous Yaqui people who continue to live their traditional territory, now the city of Hermosillo, Mexico (Hiner and McKinnon 2013). While some might find the breadth of this session overwhelming, to us attempting to bridge these outmoded dichotomies is key to making political ecology "useful" in the $21^{\text {st }}$ century (Blaikie 2012). As Robbins (2011) points out, one of the key tools of political ecology is the analytical "hatchet" which tears down or slashes away outmoded assumptions about how humans interact with the world. 
This collection of articles emerges out of a session we organized at the 2014 AAG meeting in Tampa reflecting on the continued relevance of the concept of "regional" political ecology (Hiner and McKinnon 2014). Our intention in organizing the 2014 session was to reflect on how the idea of a regional political ecology has developed since Walker's (2003) call to reject the First/Third World binary and Neumann's review of the use of the region within political ecology (Neumann 2010). As Neumann pointed out, political ecologists use the concept of the region inconsistently, perhaps not surprisingly considering the recent debates within human geography. Our sense, without a systematic review, was that the literature in political ecology has yet to fully embraced the idea of a regional frame as an alternative to the First/Third World dichotomy. Further, the emergence of urban political ecology has split the literature along another geographic binary. The inconsistent use of the concept of "region" has made the idea of a regional approach somewhat foggy and unclear.

As a result, we asked our contributors to consider the utility, function, or role of "region" within the field of political ecology, with attention to:

- $\quad$ what regional approaches add/offer;

- the possibility and/or desirability of generalizing across cases to gain insights into regional processes;

- the utility of making comparisons across regions or other variable characteristics (urban/rural, global North/South, land use types/economic base, etc.);

- $\quad$ and any developments or changes (historical, contemporary, or anticipated) in relation to regions or regional approaches.

The 2014 sessions included a set of 'on the ground' cases studies whose authors identified their work as taking a regional approach, and a lively panel discussion with established and emerging scholars who reflected on the value of regional approaches and the concept of the region more broadly (Hiner and McKinnon 2014). The set of articles in this special section developed from those sessions and, like the conference sessions, includes case studies and broader reflective pieces.

\section{Political ecology, a (sub)field built on binaries}

Political ecology has blossomed into a sprawling literature relevant to the study of regions. Scholars identifying with the field approach their work from a variety of disciplinary backgrounds (e.g., history, anthropology, sociology, geography, and more), theoretical perspectives (Marxist, feminist, critical, constructivist, materialist, (neo)deterministic, etc.) and spatial foci (the 'developing world', urban, rural, local, regional...) (Blaikie and Brookfield 1987; Forsyth 2003; Heynen 2014; Low and Gleeson 1998; McCarthy 2005; Neumann 2005; Paulson and Gezon 2005; Peet and Watts 2004; Robbins 2011; Rocheleau 2008; Rocheleau, Thomas-Slayter and Wangari 1996; Walker 2003; Walker and Fortmann 2003). In fact, the field of political ecology is so far-reaching and inclusive that even the scholarship of those who do not identify as political ecologists can become key texts for practitioners (Neumann 2005; Zimmerer 2007). The growth and development of the field has led to some spatial and theoretical divides.

Take, for example, the theoretically resolved issue of 'first' versus 'third' world political ecology. McCarthy and others once debated the distinction(s) between the so-called First and Third World (McCarthy 2002; McCarthy 2005; Neumann 2010; Robbins 2002; Walker 2003), but the developed world (in additional to the 'developing' one) has been accepted as an appropriate site for political ecological inquiry (Hurley and Halfacre 2011; Robbins 2011; Schroeder, St. Martin and Albert 2006; Walker 2003; Walker and Fortmann 2003). Indeed, some argue that rather than set up artificial boundaries between 'developing' and 'developed' worlds, scholars would be better served to locate the "third world within", utilizing theory based on observed processes rather than on preconceived conceptions of landscapes or contexts (Hurley and Halfacre 2011; Schroeder et al. 2006).

However, since most political ecology research focuses on detailed case studies of particular local sites, articles may not include a direct discussion of this historic (and often implicit) binary. In other words, 
while the argument has been largely resolved in the literature, the functional division of 'First' versus 'Third' world remains in practice as evidenced by the ways in which scholarship is placed in conversation. For example, looking at themed sections of the Journal of Political Ecology, articles often end up grouped together in a way that divides 'First World' and 'Third World' cases. Similarly, sessions at the annual meeting of the Association of American Geographers (AAG) often end up distributed along a convenient, if problematic, First/Third World binary. If the division is highlighted at all, it is often framed as one between the 'developing' and 'developed' world or the 'Global North' and 'Global South.' While the labels have changed, the implications for how scholars think about, categorize, and seek to understand the world remains largely the same.

Moreover, a new binary seems to be developing with the emergence of urban political ecology (Heynen, Kaika and Swyngedouw 2006; Keil 2003; Swyngedouw and Heynen 2003), a subfield that has produced a literature at least nominally divided between urban and rural (or exurban) political ecology (Beebe and Wheeler 2012; Cadieux 2008; McKinnon et al. in review; Walker and Fortmann 2003). This divide is purported to be both geographic and theoretical. Yet, when we consider the goals and methods described for "urban" (Heynen 2014) versus "regular" political ecology (Robbins 2011), the two are virtually the same. In short, using such broad binary frames provides an easy shorthand, but reinforces (false) dichotomies between actors (and scholars) which can restrict the conceptual range and explanatory power of the research endeavor (Hiner 2014). Specifically, such binaries reify certain hegemonic ways of viewing the processes of development and urbanization that can limit what stories political ecologists tell (Blaikie and Brookfield 1987, Neumann 2009).

\section{3. (Re)considering regional political ecologies}

While there has been considerable debate in human geography about the utility of scale (see Neumann 2009) and a related debate about the value of the region specifically (see Neumann 2010), in this collection the continuing relevance of regional approaches becomes clear. In some ways, the contributions to this special section reflect an acknowledgement of the value and applicability of classic approaches in political ecology (Robbins and Bishop 2008). At the same time, these contributions reveal complex and nuanced approaches to scalar interactions that move beyond nested scale models and the dichotomy of top-down versus bottom-up approaches to human-environment interactions. Neumann (2010) describes several interrelated issues with how the idea of the region has been utilized within political ecology. Earlier approaches to the region within political ecology tended to emphasize the role of ecology (Blaikie and Brookfield 1987; Zimmerer 1991) whereas following work in new regional geography (MacLeod and Jones 2001), beginning in the mid-90s, political ecologists have tended to focus on discursive regional formations and the social construction of regions. Neumann (2010: 372) advocates for what he calls a "a more universal and theoretically robust RPE" through attention to both discursive and material approaches, a task undertaken by authors in this Section.

The collection begins with a brief reflection from Walker (based on his comments during the AAG panel) on his intentions in writing his 2003 article and the role of the region in political ecology more than ten years later. Walker (2003) rejected the First/Third World binary within political ecology, but maintained that a focus on regional political ecology was necessary to prevent the field from becoming focused solely on local studies and local variability. Walker's piece in this collection reminds us of the importance of meso-scale phenomena in understanding human-environment interactions. Galt (2016: 130) adds that "...it is possible and desirable to generalize across cases to gain insights into regional processes" discussing the potential for increased comparative work within regions, also recently proposed by Taylor and Hurley (2016). Galt has exemplified regional and comparative approaches, advocating "scaling up" political ecology in his recent work on CSAs in California and pesticide regulation (Galt 2010, 2013).

The second point the Walker makes in his comments, which is picked up in several pieces in this Section, is how widely used and accepted the term is outside geography - and outside of the academy more broadly. The contributions of Cadieux (2016), London (2016), and Larsen (2016), all highlight their commitment to working with informants rather than extracting knowledge from communities. These cases highlight how working within community-defined regions and building upon community-developed 
understandings of regions can contribute to political ecology analysis. Larsen's article explicitly addresses how indigenous understandings of the region might help us rework the concept in light of new theorizing around materiality, networks, and the agency of non-human actors. Using an example from his work with the Cheslatta-Carrier nation in north-central British Columbia, he advocates using the indigenous concept of "regions of care" to negotiate the tensions in working with and writing about environmental engagements that are inherently in flux.

Cadieux (2016) focuses similarly on the potential of regional political ecology approaches to breach the gaps between political ecology, applied environmental science/management, and activism. She points to the emerging, contingent region as the place where the ideals of localism and community meet with the challenges of working across difference. She speaks to a deep commitment to working with a broad range of actors within a region, including students, policy makers, government officials, and activists, in a manor informed by feminist and post-colonial commitments to social and environmental justice.

London's contribution highlights a strong commitment to working with environmental justice activists, situating his work at the intersection of political ecology and environmental justice and exploring the concept of the region in both literatures. Focusing on a case study of environmental justice activism in the San Joaquin Valley of California, London demonstrates the multiple ways the region comes into play as activists negotiate new regional planning regimes and work across scales to promote "just sustainability." London's detailed analysis of this case study demonstrates how political ecology research can and should pay attention to the linked concepts of scale and region through attention to the ways that these concepts are socially constructed and contingent, created through ongoing interactions between a variety of actors. He introduces the concept of "scale dancing" to describe the way that activists move across scales, not simply "jumping" from one scale to another, but creating new levels of governance or networks of interaction through their work.

Jenkins' and Hiner's contributions both highlight the potential for comparative work to contribute to our understandings processes operating at a variety of scales. Jenkins (2016) uses a regional political ecology framework to examine recent developments in the American West around mineral extraction. Moving beyond stale Old West-New West tropes, he looks instead at the complexity of developments around the political economies of mineral extraction in this region. As he points out, through examination of three different contested sites in Utah, Arizona, and Wyoming, the resurgence of extractive Old West industries presents new challenges to our understanding of this region and shows how local variation may produce very different outcomes in particular cases. He also points out that such comparative work can capture emerging trends within a region, such as the increasing importance of management questions on private land. Hiner's vignettes, working comparatively within a region framed at a much more local scale in the Sierra Foothills of California, highlights interactions between local land use disputes and regional forces of change. Through attention to hyper-local community negotiations, Hiner (2016) exposes the ways the differing perceptions of place emerge in these conflicts. In these cases, Hiner shows how differences in ideology produce contested ecologies that defy simple dichotomous framings of rural versus urban or local versus newcomer. Using these local examples she makes connections to broad regional trends and forces such as rural restructuring and the movement of urban populations into rural communities.

Finally, Simon (2016) skillfully outlines how political ecologists might avoid conceptual confusion between the region and related concepts such as networks, assemblages, and systems: and argues that regions can and should do analytical work. Moreover, he maintains that political ecologists are well prepared to make use of the concept in more productive ways, pointing out that it is precisely political ecologists' understanding of the contingent and socially constructed nature of regions that would allow us to interrogate "simplistic, clumsy, and imprecise ways" that the concept is employed in politics, policy, and management.

\section{Producing regions that "work"}

Despite repeated calls for a regional political ecology, much literature within political ecology remains focused on local scale studies or retreats into overreliance on First/Third World or rural/urban binaries. This is perhaps not surprising considering recent debates within human geography about the region and scale (Escobar 2007, Jonas 2006, Marston, Jones and Woodward 2005). However, we maintain that regional 
approaches strengthen political ecology's relevance. And, upon examination, the pieces in this Section suggest "theoretically robust" ways for political ecologists to engage with the concept of the region (Neumann 2010).

We propose a renewed emphasis on regional approaches not only for the work that regional political ecology can do within political ecology studies, but also for the work it can do within the institutional context of knowledge production. As Blaikie (2008) points out in reflecting on the development of political ecology, political ecologists are constrained in the type of work they can produce by the day-to-day practices of work in the academy. The demands of tenure and promotion have resulted in fewer long-term studies of book length within political ecology and an increasing number of collections of article-length case studies, loosely organized into edited volumes. With this in mind, we turn to regional political ecology for its potential to serve as an organizing heuristic in thinking about how we might compare cases within regions and between regions in a more systematic and deliberate way.

Taylor and Hurley (2016) have recently argued for a more purposefully comparative political ecology in which case studies from different regions are analyzed together, in order to better understand how similar outcomes can be produced across the globe in a wide variety of regional contexts. An explicitly regional approach could also serve to address broad questions about the development of a region, which then could be utilized by individual researchers. For example Jenkins (2016) examines conservation outcomes in the context of the resurgence of mining in the American West, addressing questions posed by Robbins et al. (2009) in a critical review of literature on the New West. Galt $(2010,2016)$ has also called for increasing comparative and regional approaches within political ecology through scaling up political ecology analysis to include multi-scale and multi-method approaches. His recent work has included commodity chain analysis, critical GIS analysis, and comparative analysis of sub-regions of California, rather than focusing solely on individual case studies.

Moreover, regional political ecology, as re-conceptualized in this Section, is explicitly post-colonial, feminist, and focused on working with both human and non-human actors within region (Larsen 2016; London 2016; Cadieux 2016). Such an approach involves breaking down the binary between "the field" and the researcher's home region and engaging with informants to co-produce knowledge, moral ecologies, and regions of care. We further assert that a regional political ecology approach has the potential to assist researchers in creating a more supportive, welcoming institutional context for knowledge production, providing a means for researchers to move away from the idea of the "lone scholar," laboring away for years or decades alone, in a region remote from their home, and towards a network of scholars that can work together to critically examine their work in relation to others', constructing larger narratives in cooperation.

In sum, the articles in this compilation converge around several themes. Most prominently, the articles demonstrate a commitment to working towards normative standards (variously defined) of social and environmental justice. Second, these essays reflect an awareness of the socially constructed nature of regions, leading several of the contributors (Cadieux 2016; Larsen 2016 and London 2016) to suggest new ways of understanding the processes that construct regions. These articles suggest pathways through which political ecologists might conduct analyses that extend beyond local studies and engage with policy makers, activists, and community members, deepening understandings of how regions and regionalization impact questions of sustainability and justice.

At the close of the panel session on this topic at AAG 2014, one attendee asked (paraphrased): Given the socially constructed nature of regions, should political ecologists participate as active agents in the construction and reconstruction of regions? Our response is a cautious "yes" and the contributors to this special edition agree. As these essays show, political ecologists and geographers are well positioned to take an active role in negotiating questions of meaning and values and producing regions that work for social and environmental justice.

\section{References}

Beebe, C. and S.M. Wheeler. 2012. Gold Country: the politics of landscape in exurban El Dorado County, California. Journal of Political Ecology 19: 1-16. 
Blaikie, P.M. 2012. Should some political ecology be useful? The Inaugural Lecture for the Cultural and Political Ecology Specialty Group, Annual Meeting of the Association of American Geographers, April 2010. Geoforum 43: 231-239.

Blaikie, P.M. and H.C. Brookfield. 1987. Land degradation and society. Methuen.

Cadieux, K.V. 2016. Possible moral ecologies, the function of everyday curation, and the experience of regions. Journal of Political Ecology 23: 134-146.

Cadieux, K.V. 2008. Political ecology of exurban "lifestyle" landscapes at Christchurch's contested urban fence. Urban Forestry and Urban Greening 7: 183-194.

Escobar, A. 2007. The 'ontological turn' in social theory. A commentary on 'human geography without scale', by Sallie Marston, John Paul Jones II and Keith Woodward. Transactions of the Institute of British Geographers 32:106-111.

Forsyth, T.J. 2003. Critical political ecology: the politics of environmental science. New York: Routledge.

Galt, R.E. 2016. The relevance of Regional Political Ecology for agriculture and food systems. Journal of Political Ecology 23: 126-133.

Heynen, N.C. 2014. Urban political ecology I: the urban century. Progress in Human Geography 38: 598604.

Heynen, N.C., M. Kaika and E. Swyngedouw. 2006. In the nature of cities: urban political ecology and the politics of urban metabolism. New York, NY: Routledge.

Hiner, C.C. 2014. "Been-heres vs. come-heres" and other identities and ideologies along the rural-urban interface: a comparative case study in Calaveras County, California. Land Use Policy 41: 70-83.

Hiner, C.C. 2016. "Chicken wars", water fights, and other contested ecologies along the rural-urban interface in California's Sierra Nevada foothills. Journal of Political Ecology 23: 167-181.

Hiner, C.C. and I. McKinnon. 2013. Political ecology across the rural-urban divide: examining places, patterns, and processes "in between" (Sessions I-IV). Association of American Geographers (published conference sessions and abstracts). http://meridian.aag.org/callforpapers/program/SessionDetail.cfm?SessionID=17577

Hiner, C.C. and I. McKinnon. 2014. (Re)considering "regional" political ecologies: theory, utility, and applications (Sessions I-II). Association of American Geographers http://meridian.aag.org/callforpapers/program/SessionDetail.cfm?SessionID=19706

Hurley, P. and A. Halfacre. 2011. Dodging alligators, rattlesnakes, and backyard docks: a political ecology of sweetgrass basket-making and conservation in the South Carolina Lowcountry, USA. GeoJournal 76: 383-399.

Jenkins, J. 2016. Contested terrain of extractive development in the American West: using a regional political ecology framework to understand scale, biocentric conservation values, and anthropocentric resource utility. Journal of Political Ecology 23: 182-196.

Jonas, A.E.G. 2006. Pro scale: further reflections on the 'scale debate' in human geography. Transactions of the Institute of British Geographers 31: 399-406.

Keil, R. 2003. Urban political ecology. Urban Geography 24: 723-738.

Larsen, S.C. 2016. Regions of care: a political ecology of reciprocal materialities. Journal of Political Ecology 23: 159-166.

London, J. 2016. Environmental Justice and Political Ecology converge in the other California. Journal of Political Ecology 23: 147-158.

Low, N. and B. Gleeson. 1998. Justice, society, and nature: an exploration of political ecology. London, New York: Routledge.

MacLeod, G. and M. Jones. 2001. Renewing the geography of regions. Environment and Planning D: Society and Space 19: 669-695.

Marston, S.A., J.P. Jones, III and K. Woodward. 2005. Human geography without scale. Transactions of the Institute of British Geographers 30: 416-432. 
McCarthy, J. 2002. First world political ecology: lessons from the Wise Use movement. Environment and Planning A 34: 1281-1302.

McCarthy, J. 2005. First World political ecology: directions and challenges. Environment and Planning A 37: 953-958.

McKinnon, I., P. T. Hurley, C.C. Hiner and M. Maccarroni (in review) Uneven urban metabolisms: Toward an integrative (ex)urban political ecology of sustainability in and around the city. Urban Geography.

Neumann, R.P. 2005. Making political ecology. London: Hodder Arnold.

Neumann, R.P. 2009. Political ecology: theorizing scale. Progress in Human Geography 33: 398-406.

Neumann, R.P. 2010. Political ecology II: theorizing region. Progress in Human Geography 34: 368-374.

Paulson, S. and L.L. Gezon (eds.). 2005. Political ecology across spaces, scales, and social groups. New Brunswick: Rutgers University Press.

Peet, R. and M.J. Watts (eds.). 2004. Liberation ecologies: environment, development, social movements. New York: Routledge.

Robbins, P. 2002. Obstacles to a First World political ecology? Looking near without looking up. Environment and Planning A 34: 1509-1513.

Robbins, P. 2011. Political ecology: a critical introduction. Malden, MA: Wiley-Blackwell.

Robbins, P., Meehan, K., Gosnell, H. andS.J. Gilbertz. 2009. Writing the New West: a critical review. Rural Sociology 74: 356-382.

Robbins, P. and K.M. Bishop. 2008. There and back again: epiphany, disillusionment, and rediscovery in political ecology Geoforum 39: 747-755.

Rocheleau, D.E. 2008. Political ecology in the key of policy: from chains of explanation to webs of relation. Geoforum 39: 716-727.

Rocheleau, D.E., B.P. Thomas-Slayter and E. Wangari (eds.). 1996. Feminist political ecology: global issues and local experiences. New York: Routledge.

Schroeder, R.A., K. St. Martin and K.E. Albert. 2006. Political ecology in North America: discovering the Third World within? Geoforum 37: 163-168.

Simon, G. 2016. How regions do work, and the work we do: a constructive critique of regions in political ecology. Journal of Political Ecology 23: 197-203.

Swyngedouw, E. and N.C. Heynen. 2003. Urban political ecology, justice and the politics of scale. Antipode 35: 898-918.

Taylor, L.E. and Hurley, P.T. 2016. The broad contours of exurban landscape change. In L.E. Taylor and P.T. Hurley (eds.) A comparative political ecology of exurbia: planning, environmental management, and landscape change. Springer International Publishing.

Walker, P.A. and L. Fortmann. 2003. Whose landscape? A political ecology of the 'exurban' Sierra. Cultural Geographies 10: 469-491.

Walker, P.A. 2003. Reconsidering 'regional' political ecologies: toward a political ecology of the rural American West. Progress in Human Geography 27: 7-24.

Walker, P.A. 2016. On 'Reconsidering Regional Political Ecologies' 13 years on. Journal of Political Ecology 23: $123-125$.

Zimmerer, K.S. 1991. Wetland production and smallholder persistence: agricultural change in a highland Peruvian region. Annals of the Association of American Geographers 81(3): 443-463.

Zimmerer, K.S. 2007. Cultural ecology (and political ecology) in the 'environmental borderlands': exploring the expanded connectivities within geography. Progress in Human Geography 31: 227-244. 